\title{
The effect of small population size on the mating system of a rare clonal mallee, Eucalyptus argutifolia (Myrtaceae)
}

\author{
W. JASON KENNINGTON* \& SIDNEY H. JAMES \\ Department of Botany, The University of Western Australia, Nedlands, WA 6907, Australia
}

\begin{abstract}
Outcrossing rates, seed yields and the incidence of seed abortion were estimated in differentsized populations of a rare clonal mallee, Eucalyptus argutifolia Grayling and Brooker. Multilocus estimates of the outcrossing rate were high in most populations $\left(t_{\mathrm{m}}=0.79-0.96\right)$, and no relationship between population size and the outcrossing rate was evident. In addition, significant amounts of interspecific hybridization were found in some small populations (up to 47 per cent of the seeds assayed). These estimates were much higher than expected, as it was apparent that the potential for geitonogamous pollination far exceeded that of outcrossing. Pollination experiments indicated that $E$. argutifolia is self-compatible, and therefore the higher than expected outcrossing rates were attributed to inbreeding depression. This view was supported by substantial levels (over 50 per cent) of seed abortion. Selection against homozygotes was also evident during later stages of development, and this resulted in adult populations having genotypic proportions similar to those expected under random mating (complete outcrossing). It was suggested that this selection later in the life cycle offset the purging of early-acting lethal (and semi-lethal) recessives and may explain why even small populations maintain high genetic loads. Similar explanations may be applied to other mass-flowering eucalypts that maintain strong inbreeding depression despite a mixed-mating system.
\end{abstract}

Keywords: Eucalyptus, hybridization, inbreeding depression, outcrossing rate, seed abortion, self-fertilization.

\section{Introduction}

Ecological factors influencing outcrossing rates have been well discussed in the literature (see Brown et al., 1989). Modes of pollination, population size and density, and plant and floral architecture are all cited as factors likely to influence the mating system. In mass-flowering species in the genus Eucalyptus, the ranges in the time of anthesis within inflorescences and within branches ensure high levels of self-pollination, even though individual flowers are protandrous (Griffin, 1980). Estimates of the outcrossing rate $(t)$, however, have been found to be consistently high in these species (see Moran \& Bell, 1983; Moran, 1992). This has been attributed to deleterious recessives selectively eliminating the more homozygous progeny and, hence, amplifying the proportion of cross-pollinated products (Griffin et al., 1987; James \& Kennington, 1993). Prezygotic outcrossing mechanisms (self-incompatibility) have also been found in some eucalypt species (e.g.

*Correspondence. E-mail: wjkenn@uniwa.uwa.edu.au
Sedgley \& Smith, 1989; Ellis \& Sedgley, 1992). These species exhibit partial self-incompatibility with reduced penetration of ovules following self-pollination compared with cross-pollination. No evidence of stylar self-incompatibility has been recorded in Eucalyptus.

In small populations, elevated levels of inbreeding are expected (see Barrett \& Kohn, 1991). Under this regime, selection is thought to purge early-acting lethal and semi-lethal recessive mutations from the population, as they continually become exposed as homozygotes (Lande \& Schemske, 1985; Charlesworth \& Charlesworth, 1987; Barrett \& Charlesworth, 1991). Outcrossing rates in small populations may, therefore, be quite low, as, in the absence of a high frequency of recessive mutations, we would expect estimates of $t$ to be more reflective of the primary outcrossing rate. Self-incompatible species are also prone to low outcrossing rates in small populations, as these conditions favour the evolution of self-compatibility (see Reinartz \& Les, 1994).

Eucalyptus argutifolia Grayling and Brooker (Myrtaceae) is a rare, multistemmed (mallee) 
species endemic to Western Australia. It flowers profusely, producing thousands of predominantly insect-pollinated flowers per plant. It is also capable of clonal growth (as are other mallee species) through the repeated formation of ramets (modules) from an underground lignotuber (Jeník, 1994). Populations are restricted to small disjunct stands on a narrow coastal strip between Wanneroo $\left(31^{\circ} 45^{\prime} \mathrm{S}\right.$ $\left.115^{\circ} 48^{\prime} \mathrm{E}\right)$ and Hill River $\left(30^{\circ} 20^{\prime} \mathrm{S} 115^{\circ} 10^{\prime} \mathrm{E}\right), 120 \mathrm{~km}$ to the north. An allozyme study based on adult plants in all 15 known populations revealed that most stands contain few genets $(\leq 12)$, although one stand at Seabird was found to have a relatively large population size with approximately 420 individuals (Kennington \& James, 1997). As these populations are naturally small and occur in relatively pristine habitats, they provide an opportunity to study the effects of small population size on the mating system.

In this study, we compare the outcrossing rates, seed yields and the incidence of seed abortion in different-sized populations of $E$. argutifolia. We also compare genotypic proportions between progeny and adult plant generations to determine whether selection against homozygotes occurs during later stages of the life cycle.

\section{Materials and methods}

\section{Population descriptions}

Mating system analysis was carried out in the large population at Seabird and seven small populations: Mindarie Keys, Parrot Ridge East, Parrot Ridge South, Parrot Ridge West, Sheoak Road, Two Rocks A and Wesco Road B. An allozyme study of the genetic structure within these populations revealed that the small populations ( $\leq 12$ genets) exhibit a greater range of clone sizes than the large population at Seabird (Kennington \& James, 1997). Using data from this study, we also calculated the mean genet density for each of the small populations by dividing the number of genets by the total area of the population. Genet density was then converted to the number of genets per $100 \mathrm{~m}^{2}$ for comparison between populations and the estimate of genet density obtained for the Seabird population.

\section{Seed collection and electrophoresis}

In small populations, 20-25 fruits were collected (where possible) from each of the genets identified in the allozyme study of Kennington \& James (1997). In the large population at Seabird, a similar quantity of fruits was collected from 20 maternal plants. Maternal plants were at least $10 \mathrm{~m}$ apart and were selected throughout the range of the population, an area $70 \times 100 \mathrm{~m}$.

For each maternal plant sampled, fruits were dried at $35^{\circ} \mathrm{C}$ and the dehisced seed bulked. Seeds were germinated on moist filter paper, and 15 seedlings with newly emerged radicles were randomly selected and homogenized in $30 \mu \mathrm{L}$ of grinding buffer $\left(0.05 \mathrm{M}\right.$ borate buffer, $\mathrm{pH} 9.0,20 \mathrm{mg} \mathrm{mL}^{-1}$ PVP-40, $1 \mathrm{mg} \mathrm{mL}^{-1}$ DTT). Extracts were absorbed on $3 \times 10 \mathrm{~mm}$ wicks cut from chromatography paper and loaded onto 11 per cent starch gels for electrophoresis.

Seven enzyme systems: aspartate aminotransferase (AAT, EC 2.6.1.1), alcohol dehydrogenase (ADH, EC 1.1.1.1), glucose-6-phosphate isomerase (GPI, EC 5.3.1.9), malate dehydrogenase (MDH, EC 1.1.1.37), phosphogluconate dehydrogenase (PGD, EC 1.1.1.44), phosphoglucomutase (PGM, EC 5.4.2.2) and shikimate dehydrogenase (SDH, EC 1.1.1.25) were assayed using methods described in Moran \& Hopper (1983), with the exceptions that tetrazolium bromide was used instead of nitroblue tetrazolium, the MDH and PGD enzyme systems were run on a morpholine citrate buffer system (Moran \& Bell, 1983) rather than histidine and the $\mathrm{ADH}$ enzyme system was run on a lithium buffer system rather than histidine. The morpholine citrate and histidine gels were run at $50 \mathrm{~mA}$ for $4.5 \mathrm{~h}$ and the lithium gel at $65 \mathrm{~mA}$ for $5 \mathrm{~h}$. Electrophoresis was carried out at $4^{\circ} \mathrm{C}$.

Nine loci (Aat-3, Adh, Gpi-2, Mdh-3, Pgd-1, Pgd-2, Pgm-1, Pgm-2 and $S d h$ ) were scored and various subsets of these were used in the mating system analysis (Table 1). Numerical designations given to loci relate to their electrophoretic mobilities with the most anodal locus being scored as 1 . Genetic interpretation of banding patterns was based on open-pollinated progeny arrays and was consistent with those reported in other eucalypt studies (Moran \& Bell, 1983).

\section{Mating system and genetic analysis}

Multilocus $\left(t_{\mathrm{m}}\right)$ and mean single-locus $\left(t_{\mathrm{s}}\right)$ estimates of the outcrossing rate were calculated using the MLT computer program of Ritland (1990). This program is based on the multilocus outcrossing estimation procedure of Ritland \& Jain (1981), which assumes that progeny are derived from either random mating (outcrossing) or self-fertilization. A further assumption of this procedure is that loci used in the analysis are independent. In each population, polymorphic loci suitable for mating system 
Table 1 Sampling parameters for mating system analyses in eight populations of Eucalyptus argutifolia

\begin{tabular}{lrccc}
\hline Population & $N_{\text {est }}$ & $\begin{array}{c}\text { No. of } \\
\text { families }\end{array}$ & $\begin{array}{c}\text { Total no. of } \\
\text { progeny }\end{array}$ & Loci used \\
\hline Mindarie Keys & 1 & 1 & 15 & - \\
Sheoak Road & 2 & 2 & 21 & - \\
Two Rocks A & 5 & 4 & 60 & Gpi-2, Pgm-1, Pgm-2 \\
Parrot Ridge East & 5 & 4 & 39 & Adh, Pgd-2, Pgm-2 \\
Wesco Road B & 6 & 5 & 68 & Adh, Pgm-1, Pgm-2 \\
Parrot Ridge West & 12 & 9 & 110 & Gpi-2, Pgm-2 \\
Parrot Ridge South & 10 & 9 & 131 & Gpi-2, Pgm-1, Pgm-2 \\
Seabird & 420 & 20 & 300 & Aat-3, Adh, Pgm-2 \\
\hline
\end{tabular}

$N_{\text {est }}$ is the estimated number of genets in each population.

analysis were first tested for linkage disequilibrium using the LD86 computer program written by Weir (1990). Loci that were significantly correlated $(\alpha=0.05)$ were not used in the analysis. These loci tended to have little influence on the outcrossing estimates, as analyses that included them produced similar estimates to analyses with these loci omitted. Standard errors of the outcrossing rate estimates were based on 500 bootstraps with resampling from within families. The MLT program allows for known or unknown maternal parentage. Maternal genotypes were known for the Gpi-2, Pgd-1, Pgd-2, Pgm-2, $M d h-3$ and $S d h$ loci in all small populations and were incorporated in the analysis. In the large population at Seabird and for the Aat-3, Adh and Pgm-1 loci, maternal genotypes were unknown and inferred using the method of Brown \& Allard (1970).

Wright's fixation index $(F)$ and variance was calculated using maternal (known and inferred) and progeny genotypic frequencies for polymorphic loci in each population. Changes in $F$-values between generations will give an indication of any selection against homozygotes or heterozygotes during later stages of the life cycle. For example, a negative change in $F$-values between progeny and maternal plants would indicate selection against homozygotes as plants mature, whereas a positive change would suggest selection against heterozygotes. Estimates were based on a diallelic data set in which the frequency of the least common alleles pooled was $\geq 0.1$. The estimate of $F$ was calculated using the formula 1 - (observed heterozygosity)/(expected heterozygosity), and the variance for the maternal genotypes according to the formula of Brown (1970). Both were calculated using the GENESTRUT computer program (Constantine et al., 1994). The variance of $F$ for the progeny arrays was calculated using the formula provided by Phillips \& Brown
(1977). On the assumption that loci were statistically independent, the mean variance of $F$ was calculated over all loci for each population by dividing the mean of the variances by the number of loci (Brown \& Weir, 1983). F-values were not calculated in the Mindarie Keys and Sheoak Road populations.

\section{Detection of interspecific hybrids}

An allozyme survey of adult plants in all 15 known populations of $E$. argutifolia indicated that this species is monomorphic at three loci: Pgd-1, Pgd-2 and $M d h-3$ (Kennington \& James, 1997). This survey involved all adult plants in 14 populations and a sample of plants (six genets) from the 15th (Seabird) population. A larger sample from the Seabird population (20 inferred maternal genotypes from this study) also found no variation at these loci in adult plants. Progeny heterozygous at any of these loci are therefore likely to be interspecific hybrids. As eucalypts co-occurring with $E$. argutifolia ( $E$. foecunda Schauer, E. gomphocephala DC. and E. petrensis Brooker and Hopper) have cotyledon morphologies different from E. argutifolia (see Brooker \& Kleinig, 1990), we were able to use this character to identify hybrid seedlings and hence verify that seedlings heterozygous at $P g m-1, P g m-2$ or $M d h-3$ were of hybrid origin.

All three loci were scored in the progeny of each maternal plant investigated.

\section{Seed abortion and fecundity estimates}

An estimate of the amount of seed abortion was determined in four individual plants (two from Seabird and two from Wesco Road B) by comparing the mean number of seeds per fruit at different stages of development. Fruits of the same openpollinated cohort were sampled at an early stage of 
development (3-4 weeks after fertilization) and then as mature fruits the following year. Seeds in the developing fruits could be identified as they were ovules which were swollen and tended to be opaque. Sections from a sample of these structures confirmed the presence of an embryo. Individual means for each fruit cohort were based on 10 fruits. Differences between stages of development were compared in each individual using an unpaired $t$-test. Following Zar (1984), a Mann-Whitney test was used in cases in which data were not normally distributed.

An estimate of the proportion of ovules that develop into seeds was determined for each population (except Mindarie Keys and Sheoak Road) from the ovular contents of dehisced fruits. Ovular contents consist of seeds, late-aborted seeds (testa but no endosperm) and chaff (Boland et al., 1980). The chaff may be further divided into sterile structures, known as ovulodes (Carr \& Carr, 1962), and ovules which did not develop into seed. The proportion of ovules developing into seeds was calculated for each fruit by dividing the number of seeds by the number of potential seeds (ovules + late aborted seeds + seeds). Population means were based on the mean of five individual means (four in Two Rocks A), which were based on five fruits each. This method overestimates the proportion of ovules developing into seed per plant, as it does not take into account flowers that do not develop into mature fruits. Studies have shown this to be quite high in eucalypts (Cunningham, 1957; Florence, 1964; Ashton, 1975). However, the advantage of this method is that it tends to control for any variation in pollination success between populations. This is because unfertilized eucalypt fruit senesce (Pryor, 1951; Griffin \& Hand, 1979), but fertilized fruits appear to persist on the plant even if all embryos abort at an early stage of development. This is evidenced by mature fruits that contain no seed or seeds that are at least partially developed.

\section{Pollination experiments}

Controlled self- and cross-pollinations were carried out in two individual plants from the Seabird population. In each individual, flowers just before anthesis were emasculated by removing stamens and then bagged. After 5 days, 10 flowers with receptive (sticky) stigmas were self-pollinated, 10 cross-pollinated and two left unpollinated (controls). The relative success of the different pollination treatments was assessed in each individual by counting the number of ovules penetrated by pollen tubes.
Counts were made 5 days after pollinations and were made using aniline blue fluorescence microscopy techniques (Martin, 1959). Differences between pollination treatments in each individual were compared using an unpaired $t$-test.

\section{Results}

\section{Mating system and estimates of inbreeding}

Outcrossing rates were highly variable between populations. Multilocus estimates ranged between 0.96 (Parrot Ridge West) to 0.25 (Parrot Ridge East), although most populations had estimates in excess of 0.75 (Table 2). Mean single-locus estimates were similar to the multilocus estimates in each population (Table 2). No relationship between the outcrossing rate and population size was evident.

Genet density appeared to have no effect on the outcrossing rate, unless the density was very low $\left(<0.1\right.$ genets per $\left.100 \mathrm{~m}^{2}\right)$. Outcrossing rates in these populations were low (range $t_{\mathrm{m}}=0.25-0.38$ ) compared with the other populations of $E$. argutifolia (Table 2) and other mass-flowering eucalypts (see James \& Kennington, 1993).

In most populations, estimates of Wright's fixation index $(F)$ calculated from progeny arrays were higher than those calculated from maternal genotypes. Estimates of $F$ calculated from progeny arrays were frequently significantly positive, whereas estimates calculated from maternal genotypes were negative or not significantly different from zero in all populations (Table 3). In the Two Rocks A population, $F$ changed from significantly negative in the progeny to near zero in the maternal genotypes (Table 3).

\section{Detection of interspecific hybrids}

Interspecific hybrid seed (indicated by progeny being heterozygous at the $P g d-1, P g d-2$ or $M d h-3$ loci) was evident in all populations. In the Mindarie Keys, Sheoak Road, Two Rocks A and Parrot Ridge East populations, at least 10 per cent of the seeds analysed were of hybrid origin. The highest level of hybridization was found in the Mindarie Keys population, in which 47 per cent of the seeds analysed were of interspecific hybrid origin (Table 2). Alleles present in two co-occurring eucalypt species ( $E$. gomphocephala and $E$. petrensis) were found in hybrid seedlings.

\section{Seed abortion and fecundity estimates}

There were significantly higher numbers of seeds in the developing fruits than in the mature fruits of the 
Table 2 Multilocus $\left(t_{\mathrm{m}}\right)$ and mean single-locus $\left(t_{\mathrm{s}}\right)$ outcrossing rates and the percentage of interspecific hybrid seed in different-sized populations of Eucalyptus argutifolia

\begin{tabular}{lcccccc}
\hline Population & $N_{\text {est }}$ & $R$ & $G D$ & $t_{\mathrm{m}}$ & $t_{\mathrm{s}}$ & $\begin{array}{c}\text { Interspecific } \\
\text { hybrids (\%) }\end{array}$ \\
\hline Mindarie Keys $\dagger \ddagger$ & 1 & 160 & 1.0 & - & - & 47 \\
Sheoak Road & 2 & $20-28$ & 0.2 & - & - & 19 \\
Two Rocks A $\dagger \S$ & 5 & $2-120$ & 0.9 & $0.88(0.10)$ & $0.90(0.08)$ & 38 \\
Parrot Ridge East $\dagger$ & 5 & $2-86$ & $<0.1$ & $0.25(0.18)$ & $0.24(0.19)$ & 10 \\
Wesco Road B & 6 & $1-306$ & $<0.1$ & $0.38(0.13)$ & $0.37(0.13)$ & 1 \\
Parrot Ridge West $\$$ & 12 & $1-125$ & 1.0 & $0.96(0.08)$ & $0.94(0.08)$ & 2 \\
Parrot Ridge South & 10 & $1-46$ & 1.0 & $0.79(0.08)$ & $0.77(0.07)$ & 2 \\
Seabird§ & 420 & $1-22$ & 6 & $0.88(0.04)$ & $0.87(0.04)$ & $<0.1$ \\
\hline
\end{tabular}

Standard errors are in parentheses. $N_{\text {est }}$ is the estimated number of genets in each population. $R$ is the range of clone sizes $\left(\mathrm{m}^{2}\right) . G D$ is the mean number of genets per $100 \mathrm{~m}^{2}$.

†Population sympatric with $E$. foecunda.

$\ddagger$ Population sympatric with E. gomphocephala.

$\S$ Population sympatric with $E$. petrensis.

Table 3 Wright's fixation index based on maternal plants $\left(F_{\mathrm{m}}\right)$ and progeny $(F)$ in six populations of Eucalyptus argutifolia

\begin{tabular}{lccc}
\hline Population & No. of loci & $F_{\mathrm{m}}$ & $F$ \\
\hline Wesco Road B & 6 & $0.06(0.05)$ & $0.38(0.11)^{*}$ \\
Parrot Ridge South & 6 & $-0.27(0.04)^{*}$ & $0.12(0.02)^{*}$ \\
Parrot Ridge West & 3 & $-0.48(0.09)^{*}$ & $0.01(0.03)$ \\
Parrot Ridge East & 4 & $0.30(0.12)$ & $0.19(0.05)^{*}$ \\
Two Rocks A & 4,7 & $0.05(0.07)$ & $-0.08(0.02)^{*}$ \\
Seabird & 4 & $-0.01(0.06)$ & $0.04(0.01)^{*}$ \\
\hline
\end{tabular}

Standard errors are in parentheses.

*Denotes rejection of null hypothesis that $F=0.0$. The significance level was held constant at 0.05 for the 12 independent tests using the correction $\alpha=1-(1-0.05)^{1 / r}$, where $r$ is the number of independent tests (Lindman, 1974).

same cohort in two of the four individuals examined (Fig. 1). The remaining two individuals showed similar trends, although the differences in these plants were nonsignificant (albeit marginally so). Over all individuals, the number of seeds in mature fruits was, on average, 42 per cent (range 23-50 per cent) of that found in the developing fruits. This suggests that significant amounts of seed abortion occur between these two developmental stages.

The proportion of ovules developing into seeds in the large population at Seabird was, on average, almost four times greater than in the small populations (Fig. 2).

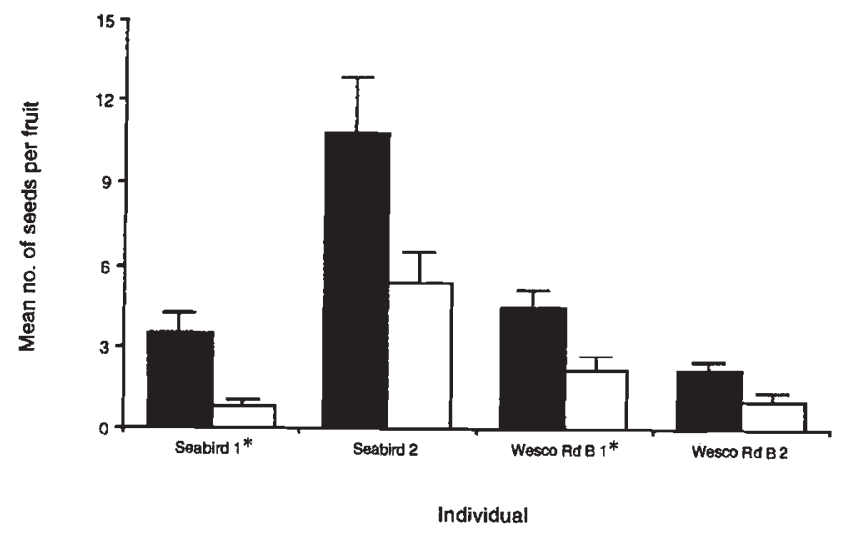

Fig. 1 Mean number of seeds per fruit in developing ( and mature ( $\square$ ) fruits of the same cohort in four individual plants of Eucalyptus argutifolia. Individuals are from populations at Seabird (Seabird 1 and 2) and Wesco Road B (Wesco Road B 1 and 2), which are characterized by large and small population sizes respectively. ${ }^{*}$ Denotes individuals with significant differences in the number of seeds per fruit between different aged fruits. The significance level was held constant at 0.05 for the four independent tests using the correction $\alpha=1-(1-0.05)^{1 / r}$, where $r$ is the number of independent tests (Lindman, 1974).

\section{Pollination experiments}

There were no significant differences in the number of ovules penetrated by pollen tubes following controlled self- and cross-pollinations in either of the plants examined (Table 4). Hundreds of pollen tubes were observed in the styles of hand-pollinated

(C) The Genetical Society of Great Britain, Heredity, 78, 252-260. 


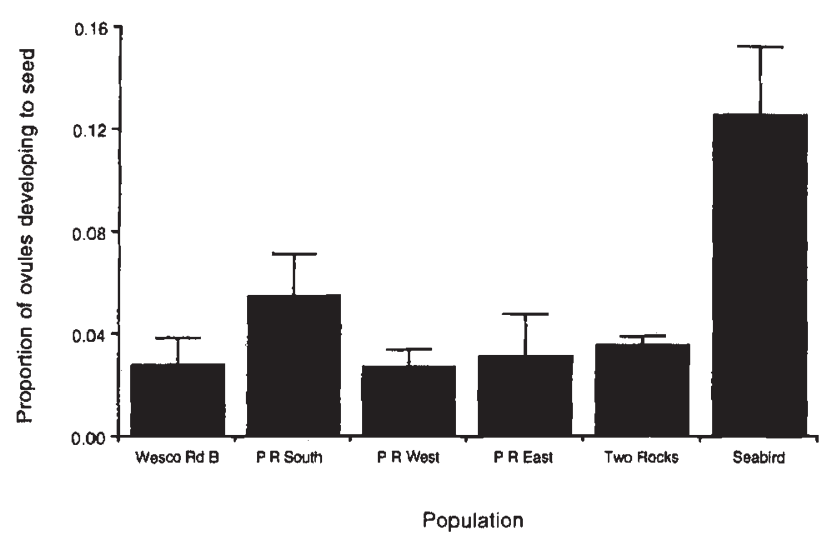

Fig. 2 Mean proportion of ovules that develop into seeds in six populations of Eucalyptus argutifolia.

flowers. There was no evidence of stylar selfincompatibility.

\section{Discussion}

Comparisons between populations of $E$. argutifolia indicate that population size has no direct relationship with the outcrossing rate. Populations with 12 or fewer genets had estimates similar to that found in a population of approximately 420 genets. This is despite more extensive clonality and lower genet densities in the small populations, both of which are factors likely to increase the level of self-pollination in these stands compared with that expected in the large population at Seabird (see Handel, 1985 and Karron et al., 1995, respectively). Nevertheless, as in all predominantly insect-pollinated, mass-flowering eucalypts, the potential for geitonogamous pollination is substantial in both large and small populations of $E$. argutifolia. Estimates of the outcrossing rate in most populations of this species are, however, extremely high $\left(t_{\mathrm{m}}=0.79-0.96\right)$, and this suggests an outbreeding mechanism operating between the stages of pollination and seed maturation.

We found no evidence of a prezygotic outcrossing mechanism operating in $E$. argutifolia. This is consistent with the self-compatibility observed in $E$. regnans (Sedgley et al., 1989), E. cladocalyx and $E$. leptophylla (Ellis \& Sedgley, 1992), but contrasts with the partial self-incompatibility observed in $E$. woodwardii (Sedgley \& Smith, 1989) and E. spathulata (Ellis \& Sedgley, 1992). As this study only assessed self-compatibility to the stage of pollen tube penetration of the ovule, we cannot discount later-acting prezygotic control of the breeding system in $E$. argutifolia, as has been recorded in species from other plant families (e.g. Kenrick \& Knox, 1985; Stace, 1995). It should be noted, however, that studies investigating early seed development in Eucalyptus have found no evidence of self-incompatibility operating between the stages of pollen tube penetration of the ovule and fertilization (Sedgley, 1989; Sedgley et al., 1989). An outbreeding mechanism operating postzygotically is a more likely cause of the high outcrossing rates in $E$. argutifolia. We found that, on average, over 50 per cent of all developing seeds abort before maturity, and this may reflect high levels of inbreeding depression being expressed at early stages of development. This interpretation is consistent with the notion that mass-flowering eucalypts, such as $E$. argutifolia, are primarily selfers, but subsequent selection against homozygotes ensures that surviving seeds are outcrossed (James \& Kennington, 1993).

Eckert \& Barrett (1994) suggested that in the selfcompatible Decodon verticillatus, postpollination mechanisms may be buffering the mating system against ecological factors that influence pollen transfer, and that this may account for the narrow range

Table 4 Mean number of ovules penetrated by pollen tubes following self- and cross-pollination in two individual plants of Eucalyptus argutifolia

\begin{tabular}{lcccc}
\hline & \multicolumn{3}{c}{$\begin{array}{c}\text { Mean no. of ovules penetrated by } \\
\text { pollen tubes }\end{array}$} & \\
\cline { 3 - 4 } Plant & $\begin{array}{c}\text { Mean no. of ovules } \\
\text { per flower }\end{array}$ & Self-pollination & Cross-pollination & Significance \\
\hline 1 & $69.8(1.4)$ & $10.5(1.4)$ & $9.9(2.5)$ & NS \\
2 & $43.0(0.9)$ & $12.4(4.3)$ & $12.4(2.7)$ & NS \\
\hline
\end{tabular}

Standard errors are in parentheses.

NS, no significant difference between pollination treatments.

The significance level was held constant at 0.05 for both of the independent tests using the correction $\alpha=1-(1-0.05)^{1 / r}$, where $r$ is the number of independent tests (Lindman, 1974). 
of outcrossing rates between populations exhibiting a wide range of size, density and patchiness. Similarly, postzygotic seed selection mechanisms (secondary outcrossing) may be minimizing variation in the mating system between populations of $E$. argutifolia. Population fecundity estimates provide some support for this notion. We found that, on average, the proportion of ovules developing into seed was four times higher in the large population at Seabird than it was in the small clonal populations. Assuming that levels of fertilization and resource availability are equivalent, this would suggest that higher levels of embryo abortion are compensating for the elevated levels of self-fertilization expected in the small stands. Thus, the breeding system operates to achieve high outcrossing rates in populations, but this occurs at the expense of fecundity. It is important to note, however, that studies in other eucalypt species indicate that the probability of embryo survival is not exclusively conditional upon genotype, but rather the level of competitive interaction between different genotypes within the fruit (Griffin et al., 1987; James \& Kennington, 1993). In the absence of outcrossed (highly heterozygous) embryos, therefore, competitively inferior selfed embryos may persist and develop into seed. This may account for the very low outcrossing rates in the highly fragmented populations at Parrot Ridge East and Wesco Road B ( $t_{\mathrm{m}}=0.25$ and 0.38 , respectively) in which pollen flow between genets is likely to be low.

Given that inbreeding depression seems to be a major factor influencing the mating system in $E$. argutifolia, it is interesting to speculate on the means by which the small populations overcome purging effects and maintain levels of recessive mutations similar to that theoretically found in the large population at Seabird. Indeed, the same question may be asked about eucalypts in general, which, despite a significant component of selfing, are susceptible to strong inbreeding depression at early stages of development (e.g. Hodgson, 1976; Phillips \& Brown, 1977; Potts et al., 1987; Tibbits, 1988). Theory suggests that a selfing rate of even a few to several per cent is sufficient to purge populations of the recessive or partially recessive lethals expressed at this stage (Lande \& Schemske, 1985). Recently, Lande et al. (1994) proposed that higher mutation rates in long-lived perennials and selective interaction between loci may act to prevent the purging of lethals unless a threshold primary selfing rate is exceeded, and that this may explain a pattern of very high early inbreeding depression and intermediate selfing rates in long-lived or partially asexual plant species. They suggest that, below the threshold selfing rate, selective interference between deleterious recessives ensures that all self-fertilized zygotes die before reproduction and that, when this rate is exceeded, enough selfed zygotes survive to become sufficiently frequent relative to outcrossed zygotes to permit selection at individual loci. In $E$. argutifolia and other eucalypt species, it may be that the threshold primary selfing rate has not been exceeded, and this may explain why lethals have not been purged. Estimates of Wright's fixation index in adult plants provide support for this notion. We found that in $E$. argutifolia, $F_{\mathrm{m}}$-values were either near zero or significantly negative, indicating that, by the time of reproductive maturity, populations consist of completely outcrossed individuals rather than a mixture of self- and cross-pollinated products. Similar patterns have been found in other eucalypt species (Fripp, 1982; Sampson et al., 1988, 1989). Thus, although eucalypts are mixed-mating at the time progeny are assayed, subsequent selection against homozygotes ensures that adults are outcrossers and, as such, populations may be expected to maintain high genetic loads (e.g. Wiens, 1984; Wiens et al., 1987). Husband \& Schemske (1995) gave a similar explanation to account for the very high inbreeding depression found in the herbaceous perennial, Epilobium angustifolium, which occurs despite a moderate rate of self-fertilization.

A further point of interest of this study has been the high levels of interspecific hybridization (up to 47 per cent of seeds assayed) observed in some of the small populations. Hybridity is a well-known phenomenon in eucalypts, but is restricted to the subgenera identified in Pryor \& Johnson's (1971) taxonomic classification (see Griffin et al., 1988). To date, reports on the incidence of natural hybridization have been based on observations of adult plants, and to our knowledge, this is the first study to quantify the frequency of interspecific hybridity in the seed lot of a natural population of eucalypts.

No adult hybrid plants were observed in any population of $E$. argutifolia, and this suggests that genetic and/or environmental factors are precluding the establishment of hybrid seedlings. In the population at Two Rocks A (conspicuous because of its high proportion of hybrid seed), this trend was reflected by the anomalous change in $F$-values from significantly negative in the progeny (indicating an excess of heterozygotes) to near zero in the adult plants. Similar patterns of cryptic hybridization may be widespread in eucalypts (particularly those with small populations) in which potentially interbreeding species coexist. If this is the case, the phenomenon will have far-reaching implications on issues such as 
the genetic purity of seed collections to the accuracy of genetic diversity studies which are based on progeny arrays.

Populations of $E$. argutifolia tended not to intermix with coexisting eucalypt species. On rare occasions where it did occur, intermixing was limited in extent and restricted to the periphery of the population. It therefore seems unlikely that the high levels of hybridization found in this study are reflective of the proportion of ovules fertilized by hybrid pollen, but rather a further consequence of strong inbreeding depression selectively eliminating all but the most heterozygous of embryos. Although these observations suggest enhanced vigour of hybrid genotypes during seed maturation, this may not be the situation at later stages of development. Indeed, several studies have reported that cross-incompatibility between some eucalypt species becomes more evident after seed maturation (see Potts et al., 1987).

This study is indicative of the strong influence inbreeding depression has on the mating system of mass-flowering eucalypts. In $E$. argutifolia, it seems that secondary outcrossing effects ensure high outcrossing rates in populations (if distances between genets are not great), even in situations in which ecological factors are likely to promote substantial levels of self-fertilization. Further, it seems that selection against homozygotes at later stages of the life cycle ensures that adult plants are completely outcrossed, and this may explain why even small populations resist purging effects and maintain high genetic loads. Similar explanations may be applied to other mass-flowering eucalypts that maintain strong inbreeding depression, despite a mixed-mating system.

\section{Acknowledgements}

We thank the Department of Conservation and Land Management (WA) for permission to collect Eucalyptus argutifolia (a gazetted Declared Rare Flora). We would also like to thank M. Kennington for field assistance, D. J. Coates, J. F. Sampson and two anonymous referees for their comments on the manuscript. This study was partially funded by Swan Portland Cement Ltd. and carried out while W.J.K. was a recipient of a University Postgraduate Research Award at the University of Western Australia.

\section{References}

ASHTON, D. H. 1975. Studies of flowering behaviour in Eucalyptus regnans F. Muell. Aust. J. Bot., 23, 399-411.
BARRETT, S. C. H. AND CHARLESWORTH, D. 1991. Effect of a change in the level of inbreeding on the genetic load. Nature, 352, 522-524.

BARRETT, S. C. H. AND KOHN, J. R. 1991. Genetic and evolutionary consequences of small population size in plants: implications for conservation. In: Falk, D. A. and Holsinger, K. E. (eds) Genetics and Conservation of Rare Plants, pp. 3-30. Oxford University Press, Oxford.

BOLAND, D. J., BROOKER, M. 1. H. AND TURNBALL, J. W. 1980. Eucalyptus Seed. CSIRO, Canberra.

BROOKER, M. 1. H. AND KLEINIG, D. A. 1990. Field Guide to Eucalypts: Volume 2. South-western and Southern Australia. Inkata Press, Melbourne.

BROWN, A. H. D. 1970. The estimation of Wright's fixation index from genotypic frequencies. Genetica, 41, 399-406.

BROWN, A. H. D. AND ALLARD, R. W. 1970. Estimation of the mating system in open-pollinated maize populations using isozyme polymorphisms. Genetics, 66, 133-145.

BROWN, A. H. D. AND WEIR, B. S. 1983. Measuring genetic variability in plant populations. In: Tanksley, S. D. and Orton, T. J. (eds) Isozymes in Plant Genetics and Breeding, Part A, pp. 219-239. Elsevier Science Publishers, Amsterdam.

BROWN, A. H. D., BURdon, J. J. AND JAROSZ, A. M. 1989. Isozyme analysis of plant mating system. In: Soltis, D. E. and Soltis, P. M. (eds) Isozymes in Plant Biology, pp. 73-86. Dioscorides Press, Portland, OR.

CARR, S. G. M. AND CARR, D. J. 1962. Convergence and progression in Eucalyptus and Symphyomyrtus. Nature, 196, 969-972.

CHARLESWORTH, D. AND CHARLESWORTH, B. 1987. Inbreeding depression and its evolutionary consequences. Ann. Rev. Ecol. Syst., 18, 237-268.

CONSTANTINE, C. C., HOBBS, R. P. AND LYMBERY, A. J. 1994. FORTRAN programs for analysing population structure from multilocus genotypic data. J. Hered., 85, 336-337.

CUNNingham, т. м. 1957. Seed production and seed fall of Eucalyptus regnans F. Muell. Aust. For, 21, 30-39.

ECKERT, C. G. AND BARRETT, S. C. H. 1994. Post-pollination mechanisms and the maintenance of outcrossing in selfcompatible, tristylous, Decodon verticillatus (Lythraceae). Heredity, 72, 396-411.

ELLIS, M. F. AND SEDGLEY, M. 1992. Floral morphology and breeding system of three species of Eucalyptus, Section Bisectaria (Myrtaceae). Aust. J. Bot., 40, 249-262.

FLORENCE, R. G. 1964. A comparative study of flowering and seed production in six blackbutt (Eucalyptus pilularis Sm.) forest stands. Aust. For. 28, 23-33.

FRIPP, Y. J. 1982. Allozyme variation and mating system in two populations of Eucalyptus kitsoniana (Luehm.) Maiden. Aust. For. Res., 13, 1-10.

GRIFFIN, A. R. 1980. Floral phenology of a stand of mountain ash (Eucalyptus regnans F. Muell.) in Gippsland, Victoria. Aust. J. Bot., 28, 393-404.

GRIFFIN, A. R. AND HAND, F. C. 1979. Post-anthesis development of flowers of Eucalyptus regnans F. Muell. and the timing of artificial pollination. Aust. For. Res., 9, 9-15. 
GRIFFIN, A. R., MORAN, G. F. AND FRIPP, Y. J. 1987. Preferential outcrossing in Eucalyptus regnans F. Muell. Aust. J. Bot., 35, 465-475.

GRIfFIN, A. R., BURGESs, I. P. AND WOLF, L. 1988. Patterns of natural and manipulated hybridisation in the genus Eucalyptus L'Hérit. - a review. Aust. J. Bot., 36, 41-66.

HANDEL, s. N. 1985. The intrusion of clonal growth patterns on plant breeding systems. Am. Nat., 125, 367-384.

HODGSON, L. M. 1976. Some aspects of flowering and reproductive behaviour in Eucalyptus grandis (Hill) Maiden at J. D. M. Keet forest research station. 2. The fruit, seed, seedlings, self-fertility, selfing and inbreeding effects. S. Afr. For. J., 98, 32-43.

HUSBAND, B. C. AND SCHEMSKE, D. w. 1995. Magnitude and timing of inbreeding depression in a diploid population of Epilobium angustifolium (Onagraceae). Heredity, 75, 206-215.

JAMES, S. H. AND KENNINGTON, w. J. 1993. Selection against homozygotes and resource allocation in the mating system of Eucalyptus camaldulensis Dehnh. Aust. J. Bot., 41, 381-391.

JENík, J. 1994. Clonal growth in woody plants: a review. Folia Geo. Phyto., 29, 291-306.

KARRON, J. D., THUMSER, N. N., TUCKER, R. AND HESSENAUER, A. J. 1995. The influence of population density on outcrossing rates in Mimulus ringens. Heredity, $\mathbf{7 5}$, $175-180$.

KENNington, w. J. AND James, s. H. 1997. Contrasting patterns of clonality in two closely related mallee species from Western Australia, Eucalyptus argutifolia and E. obtusiflora (Myrtaceae). Aust. J. Bot., in press.

KENR1CK, J. AND KNOX, R. B. 1985. Self-incompatibility in the nitrogen fixing tree Acacia retinodes. Theor. Appl. Genet., 69, 481-488.

LANDE, R. AND SCHEMSKE, D. w. 1985. The evolution of self-fertilization and inbreeding depression in plants. I. Genetic models. Evolution, 39, 24-40.

LANDE, R., SCHEMSKE, D. w. AND SCHUlTz, S. T. 1994. High inbreeding depression, selective interference among loci, and the threshold selfing rate for purging recessive lethal mutations. Evolution, 48, 965-978.

Lindman, H. R. 1974. Analysis of Variance in Complex Experimental Designs. W. H. Freeman, New York.

MARTIN, F. w. 1959. Staining and observing pollen tubes in the style by means of fluorescence. Stain Technol., 34, 125-128.

MORAN, G. F. 1992. Patterns of genetic diversity in Australian tree species. New Forests, 6, 49-66.

MORAN, G. F. AND BELl, J. C. 1983. Eucalyptus. In: Tanksley, S. D. and Orton, T. J. (eds) Isozymes in Plant Genetics and Breeding, Part B, pp. 423-441. Elsevier Science Publishers, Amsterdam.

MORAN, G. F. AND HOPPER, S. D. 1983. Genetic diversity and the insular population structure of the rare granite rock species, Eucalyptus caesia Benth. Aust. J. Bot., 31, $162-172$.
PHILlips, M. A. AND BRown, A. H. D. 1977. Mating system and hybridity in Eucalyptus pauciflora. Aust. J. Biol. Sci., 30, 337-344.

POTTS, в. M., POTTS, w. C. AND CAUVIN, в. 1987. Inbreeding and interspecific hybridization in Eucalyptus gunnii. Silvae Genet., 36, 194-198.

PRYOR, L. D. 1951. Controlled pollination of Eucalyptus. Proc. Linn. Soc., N. S. W., 76, 135-139.

PRYOR, L. D. AND JOHNSON, L. A. S. 1971. A Classification of the Eucalypts. Australian National University Press, Canberra.

REINARTZ, J. A. AND LES, D. H. 1994. Bottleneck-induced dissolution of self-incompatibility and breeding system consequences in Aster furcatus (Asteraceae). Am. J. Bot., 81, 446-455.

RITLAND, K. 1990. A series of FORTRAN computer programs for estimating plant mating systems. J. Hered., 81, 235-237.

RITLAND, K. AND JAIN, s. 1981. A model for the estimation of outcrossing rate and gene frequencies using $n$ independent loci. Heredity, 47, 35-52.

SAMPSON, J. F., HOPPER, S. D. AND JAMES, S. H. 1988. Genetic diversity and the conservation of Eucalyptus crucis Maiden. Aust. J. Bot., 36, 447-460.

SAMPSON, J. F., HOPPER, S. D. AND JAMES, S. H. 1989. The mating system and population genetic structure in a bird-pollinated mallee, Eucalyptus rhodantha. Heredity, 63, 383-393.

SEDGLEY, M. 1989. Ovule and seed development in Eucalyptus woodwardii Maiden (Symphyomyrtus). Bot. Gaz., 150, 271-280.

SEDGLEY, M. AND SMITH, R. M. 1989. Pistil receptivity and pollen tube growth in relation to the breeding system of Eucalyptus woodwardii (Symphyomyrtus: Myrtaceae). Ann. Bot., 64, 21-31.

SEDGLEY, M., HAND, F. C., SMITH, R. M. AND GRIFFIN, A. R. 1989. Pollen tube growth and early seed development in Eucalyptus regnans F. Muell. (Myrtaceae) in relation to ovule structure and preferential outcrossing. Aust. J. Bot., 37, 397-411.

stace, H. M. 1995. Protogyny, self-incompatibility, and pollination in Anthocercis gracilis (Solanaceae). Aust. $J$. Bot. , 43, 451-459.

TIBвITs, w. N. 1988. Germination and morphology of progeny from controlled pollinations of Eucalyptus nitens (Deane and Maiden) Maiden. Aust. J. Bot., 36, $677-691$.

WEIR, B. s. 1990. Genetic Data Analysis. Sinauer Associates, Sunderland, MA.

WIENS, D. 1984. Ovule survivorship, brood size, life history, breeding systems, and reproductive success in plants. Oecologia, 64, 47-53.

WIENS, D., CALVIN, C. L., WILSON, C. A., DAVERN, C. I., FRANK, D. AND SEAVEY, S. R. 1987. Reproductive success, spontaneous embryo abortion, and genetic load in flowering plants. Oecologia, 71, 501-509.

ZAR, J. H. 1984. Biostatistical Analysis, 2nd edn. PrenticeHall, Englewood Cliffs, NJ. 